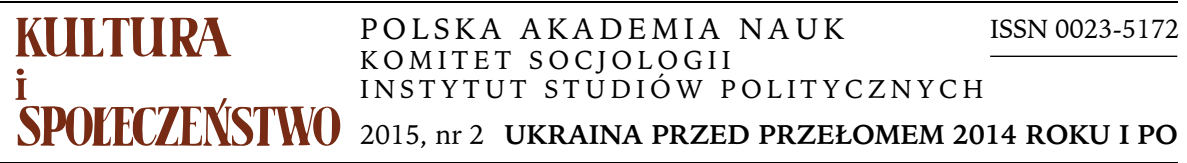

OLGA LINKIEWICZ

Instytut Historii PAN

\title{
„TA UKRAINA, TO ONA W WOJNIE I W WOJNIE...” WYOBRAŻENIA O PRZESZŁOŚCI W ŻYCIU SPOŁECZNYM ZACHODNIEJ UKRAINY PO 1991 ROKU
}

\section{ŚWIADOMOŚĆ HISTORYCZNA, PAMIĘĆ I WYOBRAŻENIA O PRZESZŁOŚCI}

Podejmuję tu krytyczną analizę materiałów etnograficznych z zachodniej Ukrainy w celu poszukiwania pojawiających się w wypowiedziach badanych odniesień do przeszłości ${ }^{1}$.

Adres do korespondencji: ola.linkiewicz@gmail.com

${ }^{1} \mathrm{~W}$ analizie sięgam do materiałów i wniosków zawartych $\mathrm{w}$ pracach licencjackich i magisterskich zgromadzonych w archiwum Instytutu Etnologii i Antropologii Kulturowej UW (AIEiAK UW). Za życzliwość i pomoc w zgromadzeniu materiałów dziękuję Bartłomiejowi Chromikowi, Ewie Nizińskiej, Wojciechowi Lipińskiemu i Jackowi Żukowskiemu. Podstawą tych studenckich prac są badania na zachodniej Ukrainie - między innymi na Polesiu, Bojkowszyźnie i pograniczu polsko-ukraińskim. Wykorzystuję również badania własne prowadzone (wspólnie z Katarzyną Łebkowską-Łoza) w trakcie pierwszych studenckich doświadczeń terenowych na Bojkowszyźnie (1997-1998), a także badania realizowane pod moim kierunkiem przez polskich i ukraińskich studentów w latach 2010-2012 (dzięki współpracy Centrum Historii Miejskiej we Lwowie i Instytutu Historii PAN, w ramach programu Geschichtswerkstatt Europa fundacji Erinnerung, Verantwortung und Zukunft), dotyczą one pamięci o miasteczkach Śniatyn i Zabłotów w obwodzie iwanofrankiwskim. Wybrane ustalenia młodych etnografów zostały opublikowane. Książka Dzisiejsze Polesie pod redakcją Wojciecha Lipińskiego (2013) jest oparta na materiałach z badań terenowych w obwodzie rówieńskim. Chociaż obszarem zainteresowania autorów są problemy współczesnego Polesia - religijność i tożsamość - wyobrażenia o przeszłości stanowią stały element narracji tożsamościowych, niezbędny do zrozumienia społecznego obrazu świata. W podobny sposób przeszłość przywoływana jest także w dotyczących obrzędowości, obyczajów i religijności opowieściach z Bojkowszczyzny, które zebrali studenci pod kierunkiem Tadeusza Baraniuka w latach 2005-2008. Niektóre oparte na nich prace zostały opublikowane w tomie Na pograniczu „nowej Europy". Polsko-ukraińskie sasiedztwo (Zowczak 2010), zawierającym wyniki badań zrealizowanych przez Magdalenę Zowczak w przygranicznych miejscowościach obwodu lwowskiego. 
Przed rokiem 1989 i na początku lat dziewięćdziesiątych etnografowie z ośrodka warszawskiego analizujący społeczne wyobrażenia o przeszłości posługiwali się terminem „świadomość historyczna”, zwykle definiując go za Gerhardem Kloską (1979, s. 114) jako „zbiór pojęć, wyobrażeń, sądów dotyczących wydarzeń z przeszłości" (zob. np. Malewska 1990). Część badaczy przyjęła za Jerzym Topolskim $(1981,1994)$ nieco inne rozumienie tego terminu, akcentujące zasób posiadanej wiedzy na temat przeszłości, jej ocenę oraz umiejętność wpisania opowieści o lokalnych wydarzeniach w historię narodową i globalną, w zamyśle konfrontując wiedzę lokalną z ustaleniami historiografii. Współcześnie termin „świadomość historyczna” jest stosowany rzadziej i zastępuje się go takimi pojęciami jak „wyobrażenia” i „wiedza potoczna o przeszłości” (Malewska 1995, 2008) oraz „pamięć”. Trudno się nie zgodzić z Jayem Winterem (2006, s. 50), że pojęcie „pamięć” jest dziś wszechobecne i jednocześnie wieloznaczne. W krytycznej analizie studiów pamięcioznawczych Kerwin Lee Klein (2000, s. 128 i 145) zwraca uwagę, że „pamięć” jako kategoria metahistoryczna jest często używana zamiast pojęcia „historia”, w miejsce „historii ludowej” czy „historii popularnej”, „historii mówionej”, a także „mitu”. Zdaniem Davida Berlinera (2005, s. 201-203), rozszerzanie zakresu pojęciowego powoduje, że pod hasłem „pamięć” rozumiany jest każdy ślad przeszłości w teraźniejszości - pokoleniowy przekaz kulturowy i trwałość elementów kulturowych, a więc właściwie kultura (por. Kończal, Wawrzyniak 2011, s. 12-13). Warto w tym kontekście odwołać się do stwierdzenia Joanny Tokarskiej-Bakir (2008, s. 53), która przypomina rzecz oczywistą, ale niesłychanie istotną: „Podstawą krytycznego badania historii jest rozróżnianie".

Poddane tu analizie materiały etnograficzne z zachodniej Ukrainy każą postawić pytanie: Czy wyobrażenia dotyczące przeszłości w badanych społecznościach możemy przypisać do kategorii pamięci zbiorowej? Niektóre omawiane narracje bez wątpienia stanowią przekazywaną pokoleniowo pamięć o przeszłości. Jednak zespół lokalnych wyobrażeń o przeszłości jako całość, moim zdaniem, do pamięci zbiorowej zredukować się nie da (zob. Kończal, Wawrzyniak 2011, s. 28). Punktem odniesienia dla zachodnioukraińskiej pamięci i niepamięci zbiorowej są dzieje narodu i mitologia narodowa (zob. np. Motyka 2013; Petrenko 2012; Rossoliński-Liebe 2014). Chociaż często opiera się ona na fikcyjnych wyobrażeniach, to ideały prawdy historycznej i obiektywizmu, czyli sine qua non uprawiania pozytywistycznej historiografii, nadają ważność i sens tej opowieści. Pozwalają one wysuwać twierdzenia o wiarygodności danego przekazu i określać go mianem świadectwa. Analizowane tu wyobrażenia odnoszą się przede wszystkim do ludowej eschatologii, mówiącej o losach człowieka i przeznaczeniu świata. Innymi słowy, społeczne ramy lokalnego dyskursu o przeszłości - wyznaczone przez sacrum - są szersze od ram zachodnioukraińskiej pamięci zbiorowej. Znaczna część obrazu przeszłości jest bowiem konstruowana na podstawie ludowej wersji Biblii (Zowczak 2013) i wywodzącej się z tego przekazu interpretacji świata. Nawet jeśli opo- 
wieści lokalne są zbliżone fabularnie do pamięci zbiorowej, odmienny punkt odniesienia powoduje, że inna jest ich symbolika, inne są też autorytety, do których odwołują się twórcy i odbiorcy tych narracji. Wzajemne oddziaływania między oficjalnym przekazem na temat przeszłości kształtowanym przed rozpadem Związku Radzieckiego, pamięcią zbiorową (w tym polityką państwa ukraińskiego wobec pamięci) i lokalnym dyskursem o przeszłości wymagają szczegółowych badań (Amar 2014).

Wyobrażenia o przeszłości są składową wiedzy lokalnej (Geertz 1983), której podstawę stanowią różne źródła - nie tylko własne lub cudze wspomnienia, ale przede wszystkim ludowa wersja Biblii i przekazywane ustnie opowieści i legendy. Dlatego społeczne ramy opowieści o przeszłości i sposób jej konstruowania są w badanych społecznościach podobne, a czasem nawet analogiczne. Ponieważ przywoływane tu materiały etnograficzne nie obejmują całej zachodniej Ukrainy, nie mogę stwierdzić, że lokalne opowieści o przeszłości na tym terenie są bez wyjątku takie same, a nawet, że funkcjonują dokładnie według tych samych reguł (por. Himka 2015, s. 130). Największa grupa analizowanych materiałów pochodzi z terenu Bojkowszczyzny i Polesia, uznawanych przez badaczy za najbardziej konserwatywne kulturowo, a nawet „archaiczne”, wobec czego wyjątkowe. Nie jest to opinia pozbawiona słuszności, choć dyskusyjna. Po pierwsze dlatego, że wspólnoty wiejskie $\mathrm{w}$ tych rejonach $\mathrm{w}$ międzywojniu podlegały dość gwałtownej erozji pod wpływem kultury miejskiej i kultury masowej. Po drugie, siła religijności ludowej także na pozostałych terenach zachodniej Ukrainy była, i jest nadal, duża i istotna społecznie. Popularyzacja ideologii narodowej i aktywność partii politycznych w życiu społeczności $\mathrm{w}$ okresie międzywojennym nie była równoznaczna $z$ utratą znaczenia tożsamości lokalnej, opartej na sakralnej interpretacji świata (Linkiewicz 2014). Trzeba zauważyć, że podobne ramy dyskursu społecznego możemy odnaleźć w innych regionach centralnej Ukrainy (Smyrski, Zowczak 2003), a także na przykład na Białorusi (Engelking 2012), Litwie (Straczuk 2006) czy we wschodniej Polsce (Buszko 2012; Tokarska-Bakir 2008). Opowieści lokalne odwołujące się zarówno do ludowej wersji Biblii, dziejów z epok dawniejszych, jak i wydarzeń z XX wieku, często mają charakter opowieści mitycznej, przypowieści bądź legendy i są wpisane w symboliczny obraz rzeczywistości. Wyobrażenia o przeszłości są więc sui generis opowieścią „świętą” bądź elementem narracji podporządkowanym całościowej, religijnej interpretacji świata.

Funkcjonowanie historii $\mathrm{w}$ formie alegorycznej paraboli jest podstawą do zrozumienia, jak wiedza o przeszłości jest wykorzystywana społecznie. Jest ona wciąż przywoływana oraz społecznie przetwarzana i pełni określone funkcje we współczesnym życiu lokalnej społeczności (zob. Assorodobraj 1963). Opowieść o przeszłości służy podtrzymywaniu tożsamości grupy i śladów dawnej hierarchii społecznej, podkreślaniu prestiżu oraz budowaniu akceptowanych społecznie norm i łatwych do odczytania ról. Wiedza o przeszłości pomaga odnieść się do aktualnych kwestii społeczno-politycznych i wypracować strategie 
zaradności społecznej. Opowieść o przeszłości może być zapisana, ale bycie w obiegu zapewnia jej przekaz ustny, który przywołuje i odtwarza ją zgodnie $z$ bieżącym zapotrzebowaniem społecznym.

Poddaję tu analizie te wyobrażenia o przeszłości, które pojawiają się w odpowiedzi na pytania o takie czy inne elementy dyskursu historycznego, ale przede wszystkim te, które są obecne w wypowiedziach na inne tematy. Innymi słowy, dokonuję wyboru treści, bo intencjonalnie dokonują go także rozmówcy. Próbuję zrozumieć, w jaki sposób wyobrażenia o przeszłości sytuują się w szerszym uniwersum symbolicznym mieszkańców i dlaczego w konkretnej sytuacji społecznej przywoływane są te a nie inne wyobrażenia (por. Bociąga 2013, s. 428; Kulik 2013, s. 461-463). W analizie stosuję wymiennie pojęcia „historia” lub „przeszłość” w odniesieniu do res gestae, czyli dziejów. Relacje o przeszłości - rerum gestarum — określam mianem „lokalnej opowieści” bądź „narracji o przeszłości”, pamięci zbiorowej oraz historiografii. Zastosowany podział wątków lokalnych opowieści o przeszłości - na opowieści „święte” i legendy, genealogie oraz wyobrażenia o historii najnowszej — jest umowny i służy uporządkowaniu materiału. Społeczne funkcjonowanie wyobrażeń o historii według zasad wyznaczanych przez ludową eschatologię pozwala bowiem na dużą dowolność $\mathrm{w}$ mieszaniu porządków i motywów $\mathrm{z}$ różnych okresów historycznych (zob. Buszko 2012, s. 105). Przykładem może być wymienne pojawianie się $\mathrm{w}$ opowieściach postaci historycznych, takich jak królowa Bona i caryca Katarzyna, czy też wpisanie wydarzeń z jednej epoki w realia drugiej jak choćby opis walk z Tatarami przywoływany przez rekwizyty i okoliczności charakterystyczne dla okresu drugiej wojny światowej (Bociąga 2013, s. 444-445; Łagoda 2013, s. 325; por. Pikula 2010, s. 363; Strojnowski 2009, s. 26).

\section{OPOWIEŚCI „ŚWIĘTE” I LEGENDY}

Lokalne opowieści o przeszłości przenikają rozmaite wątki biblijne, mityczne i legendarne. Część z nich bezpośrednio nawiązuje do ludowej interpretacji Biblii. Takie relacje określam mianem opowieści „świętych”. Należą do nich proroctwa Michaldy, królowej Saby, znane powszechnie jako sybillia lub sybilla ${ }^{2}$. Różne wersje sybillińskich przepowiedni były popularne w okresie przedwojennym i rozprowadzane na pielgrzymkach i odpustach. Na wsiach zachodniej Ukrainy i pograniczu polsko-ukraińskim (zob. Zowczak 2013, s. 223-241; Kurowski 2003) te proroctwa, zwykle anonimowe, do dziś nie tylko służą jako potwierdzenie katastroficznej wizji dziejów, ale także pozwalają mieszkańcom sformułować wytyczne właściwego, moralnego życia i potwierdzają ustalony porządek, na przykład w zakresie ról społecznych kobiet i mężczyzn (zob. Karwan 2006, s. 10; Zowczak 2013, s. 155 i nast.). Tak jak w przekazach wielu

2 Sybilla to wieszczka, która według mitologii rzymskiej sprzedała księgi proroctw (Libri Sybillini) królowi Tarkwiniuszowi Pysznemu. 
innych kultur kobieta to istota nieczysta, grzeszna Ewa, która spokusyła Adama (Karwan 2006, s. 29; Stepaniuk 2013, s. 76-88). Podobnie pozostałe wątki biblijne, w tym najczęściej przywoływane i przetwarzane opowieści z Księgi Rodzaju, objaśniają rzeczywistość i utrwalają znany obraz świata.

Narracje biblijne są zapisem wizerunku Obcego i wskazówką jak odnosić się do innych nacji. Cyganie nie pracują, bo cygańska dola jest wieczną pokutą za grzech: sprzedanie żołnierzom gwoździ, za pomocą których został ukrzyżowany Chrystus. Obecność Cyganów wywołuje nie tylko niechęć i szczególny niepokój, związany z kontaktem $z$ obcością, ale także fascynację. W podobnej roli występują w opowieściach Żydzi. Lęk przed Żydami znajduje uzasadnienie w legendach o mordzie rytualnym (Żydy pity krow), w których pojawia się motyw beczki nabijanej gwoździami (zob. Kostrzewska 2003, s. 166; Buszko 2012, s. 140-142; Engelking 2012, s. 587-603; Tokarska-Bakir 2008, s. 256-271) ${ }^{3}$. Powtarzająca się obecność Obcych w narracjach wynika z wagi obcości dla dyskursu tożsamościowego (zob. Benedyktowicz 2000; Chromik 2010, s. 31-32; Kusy 2010, s. 295-296).

Opowieści „święte” - zwracają uwagę etnografowie - towarzyszą człowiekowi, zwłaszcza w okresie świątecznym. W trakcie szopki zwanej wertepem, młodzi ludzie obchodzą wieś z kolędą. Wertep, bardzo popularny w górskich regionach zachodniej Ukrainy, jest zapisem lokalnych wyobrażeń o Obcych. Odtwarza wyobrażenia o przeszłości: można powiedzieć, że jest wiejską formą rekonstrukcji historycznej. Pełni funkcję rozrywkową i społeczną ${ }^{4}$, ale przede wszystkim edukacyjną i umoralniającą — przez wytykanie nieakceptowanych społecznie zachowań i naśmiewanie się z inności. W okresie radzieckiej Ukrainy chodzenie $z$ wertepem było manifestacją patriotyzmu (Pawlik 2009, s. 31). Na Bojkowszyźnie i Huculszczyźnie kolędowanie cieszy się sporą popularnością do dzisiaj. Uczestnictwo w nim jest świadectwem prestiżu i powodem do dumy. W ostatnich latach $\mathrm{w}$ treści scen pojawiły się nowe postacie, a inne - na przykład „Polak” - zostały uwspółcześnione (Mikulska 2007, s. 5-7 i 33; Jabłońska 2007, s. 40). Wśród kolędników wciąż można zobaczyć Cygana i Żyda, który wszystkie grosze zabiera dla siebie (Stasiak 2009/2010, s. 17).

Bohaterowie życia codziennego, którzy niegdyś pełnili w swojej społeczności szczególną funkcję - na przykład znachorzy i uzdrowiciele - w lokalnej narracji stają się postaciami mitycznymi (Chromik 2010; Sakowska 2013). W wyobrażeniach o przeszłości bieg zdarzeń, oparty na przykład na indywidualnych wspomnieniach, może płynnie przechodzić $\mathrm{w}$ legendę, przesyconą ele-

\footnotetext{
$3 \mathrm{~W}$ usłyszanej przeze mnie opowieści, wspomnienie o dziadku rozmówczyni, który sprzedawał Żydom marchew, przeplata się $z$ wątkami typowymi dla legendy - w tym o beczce znajdującej się w piwnicy, z której kapała krew (wyw. Zabłotów 2010, kobieta ur. 1932 r., rozm. O. Linkiewicz; por. Buszko 2012, s. 142).

${ }^{4}$ Jest to okazja do zachowań społecznych, na które w innych warunkach nie ma przyzwolenia. W trakcie zabawy młodzi ludzie mogą się publicznie obejmować, ściskać czy naśladować stosunek seksualny, przewracając się na siebie (Woźniak 2007, s. 13).
} 
mentami fantastycznymi i cudownymi, z której dowiadujemy się o królewnach w złotej koronie, zakopanych dzwonach, żydowskich skarbach i powojennych powrotach w poszukiwaniu skrzyń pełnych diamentów (zob. Bociąga 2013, s. 445$)^{5}$.

\section{GENEALOGIE, CZYLI WYOBRAŻENIA O GENEZIE}

Genealogie to wyobrażenia o pochodzeniu grupy i opowieści sytuujące poszczególne osoby w społeczności (zob. Chromik 2010, s. 47). Mówią one w szczególności o genezie własności oraz relacji i hierarchii społecznych. Niektóre genealogie, oparte na ludowej interpretacji Biblii, są formą opowieści „świętych”. Na przyklad szlachta wywodzi się od Jafeta, Żydzi od Sema, a chłopi od Chama, a więc człowieka prostego - prostaka (zob. Engelking 2012, s. s. 439-440; Zowczak 2013, s. 155 i nast.). Zgodnie z taką genezą każda z grup ma swój los, czyli swoją dolę.

W opowieściach o genezie mieszkańcy Polesia powracają zarówno do mitycznych czasów koliszniowo cara ${ }^{6}$, jak i okresu pańskiej włady, a więc II Rzeczypospolitej (Bociąga 2013, s. 443). W nowej sytuacji politycznej miejscowi zawierali z przyjezdymi Polakami z innych wsi rodzaj kontraktu, który służył wzajemnej pomocy i regulował stosunki społeczne w okolicy. W świetle rozmów przeprowadzonych przez Aleksandrę Najer (2013), pobratymstwo czyli braterstwo krwi - nie odnosiło się jedynie do relacji między dwiema osobami, ale też do układu między ich rodzinami. Obejmowano nim kogoś z Obcych, z kim była możliwa i opłacalna wymiana sąsiedzka $\mathrm{w}$ formie gościnności i wspólnego świętowania, a nawet wchodzenie w związki małżeńskie. „Chodziliśmy na obiad do nich... Wtedy nie mieli ludzie butów takich, chodzili w łapciach, to zajdziemy do nich do domu, zmienimy buty, przebierzemy się i idziemy do kościoła!" (Najer 2013, s. 351-357) 7.

Genealogie chłopskie krążą wokół kwestii posiadania ziemi; drobnoszlacheckie natomiast koncentrują się na rodowodzie bądź niegdyś nadanych przywilejach. To genealogie uzasadniają wyższość pochodzacego od pana, wolnego szlachtycza nad mużykiem - a więc szlachcica nad chłopem (Łagoda 2013, s. 321-339; Sakowska 2013, s. 270; Snopek 2013, s. 308-309). W Sernikach w obwodzie rówieńskim drobna szlachta $z$ rodu Poluchowiczów tłumaczy różnice społeczne przez narrację wzorującą się na biblijnej. W tej przypowieści pojawiają się synowie, którzy zostali zdegradowani za złe zachowanie i brak

\footnotetext{
${ }^{5} \mathrm{Na}$ podstawie wielu relacji ze Śniatyna i Zabłotowa, w tym wyw., Śniatyn 2010, mężczyzna ok. 50 l., rozm. Tomasz Fedor, Maksym Shvets i Yevhen Polyakov.

6 Słowo kolysznij oznacza po ukraińsku „dawny”, „niegdysiejszy”. Czasami rozmówcy precyzują, że chodzi im o cara Mikołaja.

${ }^{7}$ Nie wiemy, czy rozmówca ma na myśli kościół rzymskokatolicki czy cerkiew. Rozmówcy twierdzą, że praktykowano wymienne chodzenie do obu świątyń.
} 
szacunku wobec ojca. Tak więc chamy i kundele - czyli chłopi - wywodzą się $z$ tego samego rodu co szlachta, ale utracili na zawsze swoją pozycję. „Lepsze” i "gorsze” pochodzenie było zarzewiem konfliktu, który - choć zanika - jest widoczny w niektórych społecznościach do dzisiaj (Łagoda 2013, s. 329-330; Pikula 2010, s. 364; Snopek 2013, s. 299). Z odrębnością wiąże się doświadczanie inności i obcości sąsiadów, oswajane w rytualnych czynnościach, takich jak naśmiewanie się, bijatyki, rzucanie kamieniami - w rozmaitych demonstracjach lekceważenia i niechęci (Łagoda 2013, s. 331-333). „Jak my gdzieś przyjedziemy, to naszą mowę od razu rozpoznają... Tak każdy powie: przyjechali bulbaszestwo" (Piechowska 2013, s. 363) ${ }^{8}$. Korzenie chłopskie mogą być powodem do wstydu, wynikającego z poczucia niestosowności własnego języka, ubioru i zachowania. Podobne określenia, mające charakter przezwisk, są nośnikami wiedzy o przeszłości. Są nimi także przydomki (kliczki), odnoszące się do pochodzenia mieszkańców i ich roli społecznej (Chromik 2010, s. 47-50; Snopek 2013, s. 304).

\section{LOKALNE WYOBRAŻENIA O HISTORII NAJNOWSZEJ}

Lokalne odczytanie historii (res gestae) powoduje, że wydarzeniom często są nadawane inne znaczenia niż te przypisywane im w historiografii i nacjonalistycznym dyskursie pamięciowym. Wydarzenia te przede wszystkim muszą zostać dopasowane do ram interpretacji i pojęć, którymi operują rozmówcy. W przypadku wątków z historii najnowszej najwyraźniej widać, że utrwalana i przywoływana jest ta przeszłość, która pomaga zrozumieć współczesny świat i opracować strategie przetrwania $\mathrm{w}$ trudnych warunkach ekonomicznych. $\mathrm{Z}$ uwagi na sytuację polityczną i gospodarczą, w tym konieczność migracji zarobkowych, punktem odniesienia dla wielu społeczności lokalnych na zachodniej Ukrainie jest dzisiaj Polska. Etnografowie badający Polesie próbowali pojąć, dlaczego rozmówcy niechętnie odchodzili od przedwojennych wspomnień: recytowali wierszyki, wyciągali dokumenty i zdjęcia, opowiadając o panu, wojsku i szkole - czyli, można powiedzieć, o klasycznych formach „kolonialnej opresji" państwa polskiego na tym terenie $\mathrm{w}$ okresie międzywojennym. W gruncie rzeczy nie bardzo dało się z nimi rozmawiać na inny temat niż miniona i dzisiejsza Polszcza (Kulik 2013, s. 451-472). „Gospodarza nie ma, synu, nie ma Polski. Jak by tu była Polska, na Ukrainie, to byśmy byli zadowoleni i syci” (Bociąga 2013, s. 437) ${ }^{9}$. Z kolei Ukraińcy przesiedleni na Polesie z terenów dzisiejszej Polski podkreślali różne zalety życia w II Rzeczypospolitej, w tym „europejskość" odzieży i perspektywy, które dawała szkoła powszechna (Deja 2013, s. 414-419). Nie twierdzę, oczywiście, że stosunek do Polski na całej zachod-

\footnotetext{
8 Bulbaszestwo pochodzi od słowa bulba, słowa oznaczającego w gwarze białoruskiej ziemniaka.

${ }^{9}$ Mieszkańcy Łomska, trwający od lat przy polskiej tożsamości, oczekiwali od etnografów pomocy w repatriacji (Sokołowski 2013; Kulik 2013, s. 457, 462, 465).
} 
niej Ukrainie jest tak samo entuzjastyczny (por. Woźnica 2010, s. 396-397). Warto jednak zwrócić uwagę na fakt, że mieszkańcy idealizują przedwojenne życie w konkretnym celu. Jest nim próba adaptacji do trudnej sytuacji dziś i przyjęcie strategii, w których kontakt z Polską jest potrzebny (Kulikowska 2010, s. 123-127). Historia jest wykładnią: dającą szansę na zmiany i tłumaczącą konsekwencje ciężkiego położenia w oczekiwaniu na „lepsze czasy”.

Zasób wiedzy rozmówców o okresie przedwojennym zależy nie tylko od generacji narratora i jego/jej edukacji, ale też od statusu rodziny przed 1939 rokiem. Starsze pokolenie mieszkańców wspomina przede wszystkim polską szkołę - jedno z kluczowych doświadczeń dzieciństwa. W narracjach wiejskich częste jest wspomnienie ciężkiej pracy na gospodarstwie - pasienia zwierząt i opieki nad młodszym rodzeństwem. Prawie we wszystkich wypowiedziach powtarzają się opisy ówczesnych barier społecznych i zdominowania władzy administracyjnej przez przyjezdnych Polaków - urzędniczą inteligencję, względnie przez enigmatyczną, ale kluczową dla dyskursu tożsamościowego figurę pana. Pojawiają się też frazy zaczerpnięte $z$ języka przedwojennych ukraińskich działaczy nacjonalistycznych. „Jeszcze nie zginęła, ale zginąć musi" - takim wezwaniem przywitali nas mieszkańcy wsi Rożanka Wyżna na Bojkowszczyźnie latem 1997 roku (zob. też Bociąga 2013, s. 436). Drugi powszechny i jednakowo ogólnikowy obraz jest pozytywny a nawet nostalgiczny, zwłaszcza w przeciwieństwie do władzy radzieckiej, będącej dla znacznej części mieszkańców tego regionu usosobieniem zła (Kulikowska 2010, s. 48-50; Woźniak 2007, s. 6).

„Polacy - oni wszystkim kierowali, naczal'nykamy byli. Dziadek opowiadał, że za Polski było dobrze żyć. Dobrze. No, gorzej, gorszego nie ma od tych Ruskich. ... Wszystko [co złe] robili sowieci. Jak tutaj mówią: Moskali" 10.

Nie oznacza to jeszcze, że te schematyczne i ambiwalentne sądy są jedyną wiedzą, jaką rozmówcy mają o przedwojennym świecie. To pierwsze skojarzenia o charakterze formuly — konwencjonalnych stwierdzeń, którymi pytani posługują się najchętniej. Mają one zarysować opozycję między czasem dobrym i złym - wartościować go jako czas porządku lub chaosu (Bociąga 2013, s. 440, 449). „Nie było różnicy, zgoda była”; „...u nas nie było różnicy, kto Polak, kto Ukrainiec", słyszymy (Bociąga 2013, s. 437-438; Kulak 2000, s. 51-53; Kulik 2013, s. 460; Woźnica 2010, s. 398) ${ }^{11}$. Prawdziwą różnice w pojęciu rozmówców - czyli konflikt i konieczność zadeklarowania polskiej lub ukraińskiej narodowości - przyniosła dopiero wojna.

Mimo ówczesnych silnych napięć narodowościowych i aktywności działaczy politycznych różnych frakcji w narracjach wiejskich i małomiasteczkowych

\footnotetext{
10 Wyw., Śniatyn 2010, kobieta ur. 1935 r., rozm. T. Fedor.

11 Analogiczne wypowiedzi możemy usłyszeć od przesiedleńców z Galicji Wschodniej na Dolnym Śląsku i Ukraińców przesiedlonych na Mazury w wyniku akcji „Wisła”.
} 
odnoszących się do okresu międzywojennego dominuje opowieść o hierarchii społecznej i różnicach „cywilizacyjnych”. Takie różnice - centralne dla dyskursu tożsamościowego - są też motywem przewodnim historii na temat relacji wśród przesiedleńców (Deja 2013, s. 403-426; Pikula 2010, s. 364; Sulima 2007, s. 34-35). Hierarchiczność i trwałość modelu społecznego oraz wspomniana już obcość w dyskursie tożsamościowym były fundamentem porządku ówczesnego świata, który nadal jest zrozumiały dla rozmówców starszego pokolenia. Ponieważ w znanym z doświadczenia i opowieści układzie społecznym Polak (Polak-pan, Polak-inteligent) posługiwał się polszczyzną, niektórzy badani oczekują, że etnografowie będą mówić do nich po polsku (Woźniak 2007, s. 6).

Rozmówcy potrafią zaskoczyć słuchacza wiedzą i precyzją w zakresie podawania detali miejsca, czasu i przebiegu akcji — na przykład działań związanych z wkroczeniem wojsk sowieckich, zmianą władzy czy granic (Bociąga 2013, s. 434-436). Jednocześnie wiele opowieści ma charakter niedookreślony (Snopek 2013, s. 303). Rozmowa o przeszłości swobodnie przechodzi w rozważania nad przebiegiem procesu dziejowego, czyli w ludową historiozofię.

„No może w 39. roku, ale już wojna się zaczęła [...] to już Polacy pouciekali. Do Polski uciekli wszyscy a myśmy zostali bez żadnej władzy [...] aż przyjechali radzieccy żołnierze na koniach i powiedzieli, że już jest radziecka władza. [...] Wojna to nie daj Boże, żeby tylko nie było wojny nigdy [...] To tylko żeby ta Ameryka nie napadła na Ukrainę ${ }^{12}$ [...] A kto tam ich wie? A dlaczego ona na Irak napadła, Ameryka? [...] A na Ukrainę napadali i napadali. — "A kto napadał?» - Niemiec, Tatarzy napadali. Ta Ukraina, to ona w wojnie i w wojnie" (Bociąga 2013, s. 445-446).

Opowieści z okresu wojny mają dużą dramaturgię i rozbudowaną symbolikę. Tak jest w przypadku biografii pani Sofiji z Libuchory, która jest właściwie biografią cudzą: składa się bowiem z narracji zbudowanej wokół realnego i jednocześnie mitycznego bohatera - majora Ukraińskiej Powstańczej Armii Wasyla Mizernego. Wydarzenia towarzyszące jego śmierci, a następnie ekshumacji zwłok i pogrzebowi w 1991 roku w opowieści narratorki są wypełnione symbolami ludzkiego losu i przeznaczenia, które pomagają nadać sens przebiegowi wydarzeń i przypisywanej sobie roli (Baraniuk 2010; zob. też Sokołowski 2013 , s. 373-401) ${ }^{13}$. Opowieści kluczowe z perspektywy narratora i jego społeczności są opracowane i odtwarzane wielokrotnie. Inne - wręcz przeciwnie - są nieprzygotowaną, chaotyczną narracją, w której czas przeszły przeplata się z teraźniejszym.

Narracje powiązane $z$ ruchem nacjonalistycznym i ukraińską partyzantką są częścią pamięci zbiorowej na zachodniej Ukrainie. Dominują w przestrzeni

\footnotetext{
12 Rozmówczyni odwołuje się do oskarżeń Ukrainy o dostarczanie broni dla Iraku.

13 Podobne zabiegi narracyjne możemy zaobserwować w historii Oli Ilkiv, przedstawionej w filmie Three Stories of Galicia, reż. Olha Onyszko, Sarah Farhat, 2010.
} 
publicznej, zwłaszcza miast i miasteczek, i są popularne także w lokalnych opowieściach. Jednak stwierdzenie, że cała wieś uznaje proupowskie postawy za „swoje”, byłoby przesadą. Dość często słyszałam w terenie dezaprobatę dla działań UPA i upamiętniania tej formacji, zwłaszcza z ust starszego pokolenia rozmówców. Nie mam wystarczającego materiału, żeby próbować wyczerpująco odpowiedzieć na pytanie o to, jak rozmówcy opisują i interpretują ludobójstwo dokonane na Polakach na Wołyniu i w Galicji Wschodniej. Część z nich - zgodnie z ukraińską narracją nacjonalistyczną - uważa zbrodnie UPA za „radziecką propagandę” (Woźnica 2010, s. 396-397, 398-399; 2014, s. 48-53) lub twierdzi, że wówczas „Wszyscy się nawzajem mordowali” (Woźnica 2010, s. 398). Inni milczą lub oceniają UPA negatywnie, wobec czego nie chca, żeby odium bandy spadło na ich wieś. Określenie banderowcy, tak jak i inne o charakterze przezwisk, jest w narracjach sytuacyjne. Na Bojkowszczyźnie na przykład tak nazywani są Ukraińcy, którzy zostali przesiedleni na miejsce tamtejszych Polaków (Kobza 2010, s. 416-417; Strojnowski 2009, s. 26).

Ponieważ wiedza mieszkańców na temat drugiej wojny światowej, opierająca się często na własnych wspomnieniach, nie jest tożsama $z$ dyskursem pamięci $\mathrm{w}$ sferze publicznej kształtowanym przez politykę państwa, w tym z jego przemilczeniami i przekłamaniami (zob. Himka 2013; Rudling 2011; Stryjek 2014), rozmówcy opowiadają o Holokauście, także niepytani ${ }^{14}$. Rozpiętość opinii i ocen formułowanych w stosunku do konkretnych wydarzeń, a także w ogóle sąsiadów-Żydów, jest duża: od antysemickich wypowiedzi byłych członków UPA do relacji osób, dla których Zagłada była doświadczeniem traumatycznym (zob. Nizińska 2012; Lehmann 2001, s. 145-155). Ale w lokalnych wyobrażeniach przeważa obraz Żyda mający korzenie w ludowej wersji Biblii. Dlatego zagłada społeczności żydowskiej jest tłumaczona odpowiedzialnością Żydów za śmierć Chrystusa: „...skoro wzięli za Jezusa Chrystusa krew...”; „za to, że oni zniszczyli Jezusa Chrystusa” (Bociąga 2013, s. 448). Tak jak i w Polsce czy na Białorusi nieobecni Żydzi są nadal obecni w dyskursie tożsamościowym - funkcjonują w wyobrażeniach o przeszłości, w których plany mityczny i życia codziennego przenikają się i uzupełniają (zob. Kostrzewska 2003, 160-173). Żydzi są przywoływani w rozmowach nie tylko na temat obecnej sytuacji w Izraelu, ale i na Ukrainie: „To już Żydzi lepsi jak nasz naród, durniejszych jak Ukraińcy nie ma na białym świcie" (Bociąga 2013, s. 438).

Wyobrażenia o historii najnowszej, obudowane bogatą symboliką, mogą być wytłumaczeniem zasad rządzących światem - przedstawiają jego dzieje jako odwieczną walkę dobra i zła (zob. Skobelewa 2013; Kurowski 2003). Apokalipsie zapobiega modlitwa za grzeszników — istotna powinność żyjących (Jabłońska 2007, s. 67). Poszczególne wątki w lokalnych narracjach o przeszłości są

14 Co naturalnie nie oznacza, że wszyscy byli i obecni członkowie przedwojennych wspólnot chcą o tym pamiętać. Podobnie jest w przypadku mordów na Polakach (Bartov 2007; Nowak 2011, s. 64). 
zatem interpretowane w ramach religijnego oglądu rzeczywistości. Klasycznym przykładem jest narracja „czarnobylska”, za pomocą której mieszkańcy różnych regionów próbują włączyć swoją lokalną opowieść w narrację znaną z obiegu ustnego i medialnego. Religijna interpretacja tego wydarzenia pozwala wpisać je w katastroficzną wizję dziejów. Skutki napromieniowania po awarii elektrowni w Czarnobylu to, jak pokazuje Anna Piłat, z uwagi na swoją nieuchronność jakby zakaźna choroba. Jednocześnie tych skutków można się pozbyć, przez „strzepanie” czy „wywietrzenie” (Piłat 2013, s. 135). Stosunek wobec skażenia przypomina przedwojenny dyskurs wiejski na temat „czepiających się" chorób, które - spersonifikowane lub zanimizowane - mieszkańcy Podola próbowali „zdjąć z siebie” różnymi metodami, ze sprzedaniem kurki Moszkowi włącznie (Spittal 1938). W miejscach w mniejszym lub większym stopniu dotkniętych skutkami katastrofy narracja „czarnobylska” jest żywa (niemalże namacalna) i przetwarzana w dyskursie społecznym, tak jak przedmioty pochodzące z szabru zamkniętej strefy wciąż krążą między ludźmi (Piłat 2013, s. 129).

Okres radzieckiej Ukrainy jest przywoływany i jako czas idylliczny — pozbawiony trosk, lepszy niż rzeczywistość po rozpadzie (Gołębiewski 2010, s. 175; Kulak 2000, s. 43) - i jako czas cierpienia. Obrazy te są sprzeczne tylko z zewnętrznego punktu widzenia. Narracje o przeszłości w omawianych społecznościach funkcjonują bowiem nie w sposób linearny, ale raczej paralelnie jako osobne byty. To znaczy, że występujące w narracjach wątki zwykle nie łączą się w jedno. Na przykład pierwsze, wyjątkowo ciężkie dla rozmówców lata wprowadzania kołchozów nie zostaną zestawione z okresem „raju” za Breżniewa jako z częścią tego samego systemu politycznego (Pawlik 2009, s. 27). Wspólna wiedza na temat okresu sprzed 1991 roku — radjanskiej wtady — pozwala wskazać i napiętnować tych, którzy przyjęli „nową wiarę”. Komunistów odróżnia się od „partyjnych” i nie wpuszcza dalej niż do przedsionka cerkwi (Pawlik 2009, s. 23; 2010, s. 370-373; Pikula 2010, s. 365; Stepaniuk 2013, s. 81). O przykładzie prawdziwego komunisty mówi nam przypowieść z Trójcy (pow. śniatyński), o mężczyznie, którego dosięgła kara boska: zginął tragicznie za niszczenie krzyży i kapliczek w okresie ZSRR ${ }^{15}$. Analogiczne opowieści, często zakończone samobójstwem bezbożnika - „judaszową" śmiercią - są powtarzane powszechnie (Chromik 2010, s. 53-60; Pawlik 2009, s. 40-43). Przykłady odejścia od komunizmu na rzecz ukraińskiej racji narodowej to z kolei przypowieści o nawróceniu grzeszników (Pawlik 2009, s. 32). Wszystkie podobne relacje opowiadają o pogrążeniu się świata w chaosie i jego symbolicznym powrocie do ładu. Łączy je nie tylko fabuła, ale też konstrukcja, której istotnym elementem jest zwiastun — zapowiedź nieszczęścia. Zwiastun tłumaczy bieg wydarzeń, zastępując przyczynę w porządku przyczynowo-skutkowym (Chromik 2010, s. 67-68).

15 Zabłotów, pow. śniatyński, 2010 (notatki z rozmów). 
Niezależnie od negatywnych bądź pozytywnych doświadczeń związanych z poprzednim ustrojem rozmówcy w większości traktują go jednakowo - jako swoją dolę daną od Boga, a więc naturalny stan rzeczy, do którego trzeba było się dostosować. Temu służyły pragmatyczne strategie działania bazujące na silnej solidarności rodzinnej i wspólnotowej - można do nich zaliczyć na przykład kradzież materiałów i surowców z kołchozów i zakładów pracy oraz łapówkarstwo (Dziwani 2010, s. 275-283; Pawlik 2009; Wąsowska 2010, s. 260-261). Rację ma Joanna Kusy (2010), gdy traktuje transformację zachodzącą w społeczeństwie ukraińskim jako przykład przejścia od społeczeństwa losu do społeczeństwa wyboru: transformację długotrwałą i, moim zdaniem, nadal będącą w toku.

Temat zróżnicowania wewnętrznego Ukrainy ze szczególną siłą powrócił w okresie rewolucyjnych przemian z przełomu 2013 i 2014 roku. W tle po raz kolejny pojawiło się to samo pytanie: co wiemy o tożsamości Ukraińców zamieszkujących tak ogromny obszar - na przykład o religii, języku, a także popularnym obrazie historii czy polityki na Ukrainie? W odniesieniu do zachodniej Ukrainy wiedza o przeszłości jest zwykle utożsamiana z nacjonalistycznym dyskursem pamięci zbiorowej, kształtowanym przez znaczącą część zachodnioukraińskich elit politycznych i intelektualnych. Analiza materiałów etnograficznych pokazuje, że wiedza ta jest $\mathrm{w}$ istocie znacznie bardziej zróżnicowana. Wydaje się ponadto, że co najmniej do 2010 roku na tych terenach utrzymywała się silna odrębność grupowa i lokalna. Oczywiście taka odrębność nie ma charakteru separatystycznego, a nawet nie stanowi konkurencji dla wizji świata kreowanej w dyskursie nacjonalistycznym. Chodzi tu raczej o poczucie kulturowej („cywilizacyjnej”) inności i obcości, na przykład wobec sąsiadów-przesiedleńców, sąsiednich wsi czy regionów, i o związane z nim wyobrażenia.

Z odgórnym propagowaniem określonej, narodowej wizji historii na Ukrainie mamy do czynienia od kilkunastu lat. Oczywiście wpływ tej wizji na młode pokolenie Ukraińców na zachodzie kraju jest i będzie znaczący (zob. Stryjek 2014, s. 262-266). Dzieci uczęszczają na zajęcia z narodoznawstwa, ukraińskiego odpowiednika etnografii. Edukacja narodowa i regionalna jest prowadzona przez nauczycieli, muzealników i miłośników krajoznawstwa często $z$ własnej inicjatywy i na zajęciach pozalekcyjnych. Na przykład w Samborze na początku lat dziewięćdziesiątych nauczyciele i uczniowie zbierali i zapisywali opowieści starszych ludzi, pieśni i folklor. Kolejne roczniki zdobywały wiedzę już na podstawie książek i eksponatów muzealnych. „Uczą się tradycji, jaka jest na zachodniej Ukrainie", podkreśla $w$ rozmowie $z$ etnografem jedna $z$ nauczycielek. „Na geografii uczą się o zasięgu Bojków: jakie są przedmioty i charakterystyczne dla nich narzędzia pracy" - tłumaczy pracownica muzeum (Kubisz 
2006, s. 22). Uczniowie poznają więc pewne „obiektywne fakty”. W wypowiedziach zwracają uwagę dwie kwestie - po pierwsze, ograniczenie zakresu nauki przedmiotu do tradycji ludowej zachodniej części kraju, a po drugie bardzo tradycyjny sposób rozumienia problematyki tożsamościowej — zasadniczo odbiegający od rzeczywistości wiejskiej i współczesnej wiedzy na temat tożsamości. Edukacja utrwala statyczny, stereotypowy obraz „archaicznej” kultury wiejskiej, w której dziewiętnastowieczni działacze upatrywali prawdziwego ducha narodu. Jeśli zadaniem edukacji jest przede wszystkim „rozwijanie miłości do Ukrainy" (Kubisz 2006, s. 43), to ukrainizacja musi być traktowana priorytetowo w stosunku do poznawania różnorodności regionalnej (zob. Piechowska 2013, s. 368-369).

Naturalnie nie sposób przewidzieć, jak przemiany ostatnich lat mogą wpłynąć na lokalną wiedzę o przeszłości, a co za tym idzie - na dyskurs tożsamościowy. Społeczności lokalne na Ukrainie po rozpadzie ZSRR poddawane są intensywnym zmianom, wobec czego ta sama wieś pod koniec lat dziewięćdziesiątych to dziś $\mathrm{w}$ znacznej mierze różne światy. W wyniku migracji do miast, czasowych migracji zarobkowych na wschód Ukrainy oraz od kilku lat masowych wyjazdów do pracy zagranicę - do Polski, Niemiec, Rosji, Węgier i na południe Europy - wieś „starzeje się” i wyludnia, a działki i małe gospodarstwa służą jedynie na własne potrzeby rodziny (Jelonek 2009, 2010; Markiewicz 2010, s. 147-159). Młode pokolenie szuka zatrudnienia w pozarolniczych sektorach rynku pracy. Jaka będzie rola lokalnych wyobrażeń o przeszłości w zmieniających się warunkach, w tym w relacjach między coraz lepiej skomunikowanymi społecznościami lokalnymi? Czy ramy sakralnej interpretacji świata, w których funkcjonuje wiedza o przeszłości, mogą $\mathrm{w}$ tej sytuacji przetrwać czy raczej zostaną zapomniane wraz z odejściem starszego pokolenia mieszkańców? Można się spierać o to, w jakim stopniu omówione tu model społeczny i wizja świata są nadal aktualne, a w jakim należą już do przeszłości.

Nie tylko stosunkowo silne tradycje nacjonalistyczne na zachodzie kraju, ale także ponad dwadzieścia lat życia w niepodległym państwie spowodowały, że mieszkańcy powszechnie utożsamiają się z politycznym bytem niepodległej Ukrainy. Nie zmienia to faktu, że lokalna tożsamość społeczna i wyraźna odrębność grupowa nadal odgrywają ogromną rolę i są wciąż przetwarzane w debacie społecznej (zob. Piechowska 2013, s. 358-371). Nic więc dziwnego, że w skali całego kraju - w znacznie bardziej pluralistycznej rzeczywistości - wprowadzanie na siłę jednego języka i jednej wizji historii narodowej kilka lat temu wywoływało społeczne niezadowolenie i niechęć do władzy (zob. Kościesza 2010; Lipiński 2014, s. 15-16; por. Himka 2015; Portnov 2013; Rudling 2011). Czy w przypadku obecnej polityki edukacyjnej i historycznej będzie podobnie? Pozostaje tylko mieć nadzieję, że bogactwo kulturowe Ukrainy wynikające $z$ lokalnej różnorodności nie przejdzie zbyt szybko do historii. 


\section{BIBLIOGRAFIA}

Amar Tarik C., 2014, A Disturbed Silence: Discourse on the Holocaust in the Soviet West as an Anti-Site of Memory, w: Michael David-Fox, Peter Holquist, Alexander M. Martin (red.), The Holocaust in the East: Local Perpetrators and Soviet Responses, University of Pittsburg Press, Pittsburg.

Assorodobraj Nina, 1963, „Żywa historia”. Świadomość historyczna: symptomy i propozycje badawcze, „Studia Socjologiczne”, nr 2.

Baraniuk Tadeusz, 2010, Symboliczne obrazy lat wojny. Narracje z pogranicza, w: Magdalena Zowczak (red.), Na pograniczu „nowej Europy”. Polsko-ukrainskie sasiedztwo, DiG, Warszawa.

Bartov Omer, 2007, Erased: Vanishing Traces of Jewish Galicia in Present-Day Ukraine, Princeton University Press, Princeton.

Benedyktowicz Zbigniew, 2000, Portrety „obcego”. Od stereotypu do symbolu, Wydawnictwo UJ, Kraków.

Berliner David C., 2005, The Abuses of Memory: Reflections on the Memory Boom in Anthropology, „Anthropological Quarterly”, t. 78, nr 1, s. 197-211.

Bociąga Przemysław, 2013, Poleska mitologia. Świadomość historyczna i dziedzictwo mieszkańców Polesia, w: Wojciech Lipiński (red.), Dzisiejsze Polesie, DiG, Warszawa.

Buszko Paweł, 2012, „Żyd Żydem”. Wizerunek Żyda w kulturze ludowej podlaskich prawostawnych Białorusinów. Miasteczko Orla, Instytut Slawistyki PAN, Warszawa.

Chromik Bartłomiej, 2010, „Bohaterowie prawie mityczni. Narracje z Bojkowszczyzny”, AIEiAK UW, Lic. 656, Warszawa.

Deja Małgorzata, 2013, Przesiedleni i miejscowi. Procesy asymilacyjne na przykładzie ludności przesiedlonej ze wschodnich terenów Polski do rejonu rokitniańskiego, w: Wojciech Lipiński (red.), Dzisiejsze Polesie, DiG, Warszawa.

Dziwani Barbara, 2010, Co mieszkańcy Boryni wynieśli z lokalnej piekarni?, w: Magdalena Zowczak (red.), Na pograniczu „nowej Europy”. Polsko-ukrainskie sasiedztwo, DiG, Warszawa.

Engelking Anna, 2012, Kotchoźnicy. Antropologiczne studium tożsamości wsi białoruskiej przełomu XX i XXI wieku, Wydawnictwo Naukowe UMK, Toruń.

Geertz Clifford, 1983, 'From the Native's Point of View': On the Nature of Anthropological Understanding, w: Clifford Geertz, Local Knowledge: Further Essays in Interpretive Anthropology, Basic Books, New York.

Gołębiewski Jakub, 2010, Drobny handel wahadłowy na pograniczu polsko-ukrainskim w ujęciu antropologicznym, w: Magdalena Zowczak (red.), Na pograniczu „nowej Europy”. Polsko-ukraińskie sasiedztwo, DiG, Warszawa.

Himka John-Paul, 2013, The Reception of the Holocaust in Postcommunist Ukraine, w: John-Paul Himka, Joanna Beata Michlic (red.), Bringing the Dark Past to Light: The Reception of the Holocaust in Postcommunist Europe, University of Nebraska Press, Lincoln-London.

Himka John-Paul, 2015, The History behind the Regional Conflict in Ukraine, „Kritika: Explorations in Russian and Eurasian History", t. 16, nr 1, s. 129-136.

Jabłońska Jagoda, 2007, „Znaczenie modlitwy w życiu mieszkańców ukraińskich Bieszczadów Wschodnich", AIEiAK UW, Lic. 539, Warszawa.

Jelonek Aleksandra, 2009, „Migracje zarobkowe a funkcjonowanie rodziny na bojkowskiej wsi: ci, którzy wyjeżdżają — ci, którzy zostają", AIEiAK UW, Lic. 653, Warszawa.

Jelonek Aleksandra, 2010, Magdalena Zowczak (red.), Na pograniczu „nowej Europy”. Polsko-ukraińskie sasiedztwo, DiG, Warszawa.

Karwan Katarzyna, 2006, „Między Ewą a Bogurodzicą. Obraz kobiety w chrześcijaństwie obrządku wschodniego w wypowiedziach mieszkańców pogranicza ukraińsko-polskiego", AIEiAK UW, Lic. 455, Warszawa. 
Klein Kerwin Lee, 2000, On the Emergence of Memory in Historical Discourse, „Representations”, nr 69: Grounds for Remembering, s. 127-150.

Kloska Gerhard, 1979, Świadomość historyczna i jej badanie, „Lud”, t. 63, s. 113-140.

Kobza Paulina, 2010, Rola milczenia w pamięci o historii mieszkańców pogranicza, w: Magdalena Zowczak (red.), Na pograniczu „nowej Europy”. Polsko-ukrainskie sasiedztwo, DiG, Warszawa.

Kończal Kornelia, Wawrzyniak Joanna, 2011, Polskie badania pamięcioznawcze. Tradycje, koncepcje, (nie)ciagtości, „Kultura i Społeczeństwo”, nr 4.

Kostrzewska Olga, 2003, Wizerunek Żyda. Mit i plotka, w: Łukasz Smyrski, Magdalena Zowczak (red.), Podole $i$ Wotyń. Szkice etnograficzne, DiG, Warszawa.

Kościesza Katarzyna, 2010, „Tożsamość narodowa na pograniczu — zakarpaccy Rusini, AIEiAK UW", M. 904, Warszawa.

Kubisz Justyna, 2006, „Region i regionalizm w działalności animatorów kultury z Przeworska i Sambora", AIEiAK UW, Lic. 472, Warszawa.

Kulak Katarzyna, 2000, „Tożsamość etniczna w małżeństwach mieszanych na pograniczu polsko-ukraińskim", AIEiAK UW, M. 504, Warszawa.

Kulik Katarzyna, 2013, Wspomnienie raju utraconego i wizerunek Polaka katolika, czyli kilka czynników ksztattujacych relacje $w$ terenie, w: Wojciech Lipiński (red.), Dzisiejsze Polesie, DiG, Warszawa.

Kulikowska Anna, 2010, Wspótczesne Eldorado? Wschód i Zachód w narracjach migrantów z Betza i okolic, w: Magdalena Zowczak (red.), Na pograniczu „nowej Europy”. Polsko-ukraińskie sasiedztwo, DiG, Warszawa.

Kurowski Karol, 2003, Apokalipsa ludowa, w: Łukasz Smyrski, Magdalena Zowczak (red.), Podole $i$ Wotyń. Szkice etnograficzne, DiG, Warszawa.

Kusy Joanna, 2010, Postawy wobec żebractwa jako wyraz zmiany społecznej: od „spoteczeństwa losu” do „społeczeństwa wyboru” (zachodnia Ukraina), w: Magdalena Zowczak (red.), Na pograniczu „nowej Europy". Polsko-ukraińskie sasiedztwo, DiG, Warszawa.

Lehmann Rosa, 2001, Symbiosis and Ambivalence: Poles and Jews in a Small Galician Town, Berghahn Books, New York-Oxford.

Linkiewicz Olga, 2010, Przypadek Śniatynia. Interdyscyplinarne badania nad pamięcia o przedwojennym miasteczku, „Academia”, nr 4, s. 4-10.

Linkiewicz Olga, 2014, Peasant Communities in Interwar Poland's Eastern Borderlands: Polish Historiography and the Local Story, „Acta Poloniae Historica”, nr 109, s. 28-34.

Lipiński Wojciech, 2013, Dzisiejsze Polesie. Z etnografii pótnocnej Rówieńszczyzny, w: Wojciech Lipiński (red.), Dzisiejsze Polesie, DiG, Warszawa.

Lipiński Wojciech, 2014, Wprowadzenie - poznając Budziak, w: Wojciech Lipiński (red.), Bałkany na Ukrainie. Bułgarzy, Gagauzi i Albańczycy z ukraińskiego Budziaku, Wydawnictwo UW, Warszawa.

Łagoda Marta, 2013, „Szlachta” i „mużyki” w Sernikach - pamięć o dawnych podziałach stanowych, w: Wojciech Lipiński (red.), Dzisiejsze Polesie, DiG, Warszawa.

Malewska Anna, 1990, Świadomość historyczna mieszkańców Narola, „Etnografia Polska”, t. 34, z. 1-2.

Malewska Anna, 1995, Zarys tradycji stosowania pojęcia „wiedza potoczna”, „Etnografia Polska”, t. 39, z. $1-2$.

Malewska Anna, 2008, Wyobrażenia o państwie i władzy we wsiach nowotarskich 1999-2005, DiG, Warszawa.

Mańkowski Andrzej E., 1993, „Katolicy: Polacy czy Ukraińcy. Z badań nad pamięcią przeszłości i tożsamością religijno-narodową rzymskich katolików na środkowej Ukrainie”, AIEiAK UW, M. 417, Warszawa.

Markiewicz Józef, 2010, Kobieca migracja zarobkowa do Europy Zachodniej na tle ukraińskiego dyskursu tożsamości, w: Magdalena Zowczak (red.), Na pograniczu „nowej Europy”. Polsko-ukraińskie sasiedztwo, DiG, Warszawa. 
Mikulska Anita, 2007, „Wertep na Bojkowszyźnie. Między obrzędem a teatrem”, AIEiAK UW, Lic. 543, Warszawa.

Motyka Grzegorz, 2013, Cień Kłyma Sawura. Polsko-ukraiński konflikt pamięci, Wydawnictwo Oskar-Muzeum II Wojny Światowej, Gdańsk.

Najer Aleksandra, 2013, „Mój dom jest twoim domem”. O pobratymstwie w Kamianem i okolicy, w: Wojciech Lipiński (red.), Dzisiejsze Polesie, DiG, Warszawa.

Nizińska Ewa, 2012, „Rodzina Wołoszynów. Etnograficzne spotkania na polsko-ukraińskim pograniczu", AIEiAK UW, M. 955, Warszawa.

Nowak Jacek, 2011, Społeczne reguty pamiętania. Antropologia pamięci zbiorowej, Nomos, Kraków.

Olszański Tadeusz A., 2015, Nowe tendencje w ukrainskiej polityce historycznej, „Analizy Ośrodka Studiów Wschodnich", 4 lutego.

Pawlik Aleksandra, 2009, „Czerwona gwiazda, biała soroczka - rzecz o bojkowskich komunistach", AIEiAK UW, Lic. 619, Warszawa.

Pawlik Aleksandra, 2010, Zowczak Magdalena (red.), Na pograniczu „nowej Europy”. Polsko-ukraińskie sasiedztwo, DiG, Warszawa.

Petrenko Olena, 2012, Anatomy of the Unsaid: Along the Taboo Lines of Female Participation in the Ukrainian Nationalistic Underground, w: Maren Röger, Ruth Leiserowitz (red.), Women and Men at War: A Gender Perspective on World War II and Its Aftermath in Central and Eastern Europe, DHI-Fibre, Osnabrück.

Piechowska Maria, 2013, O identyfikacji narodowej mieszkańców wiosek przygranicznych rejonu rokitniańskiego, w: Wojciech Lipiński (red.), Dzisiejsze Polesie, DiG, Warszawa.

Pikula Jan, 2010, Różne wizje przeszłości w skonfliktowanej spoteczności Matkowa, w: Magdalena Zowczak (red.), Na pograniczu „nowej Europy”. Polsko-ukraińskie sasiedztwo, DiG, Warszawa.

Piłat Anna, 2013, „Teraz ona jakby trochę odeszła, ale my radianty...”. Radiacyjna topografia $i$ natura promieniotwórczego skażenia w percepcji społecznej na Polesiu, w: Wojciech Lipiński (red.), Dzisiejsze Polesie, DiG, Warszawa.

Portnov Andriy, 2013, Memory Wars in Post-Soviet Ukraine (1991-2010), w: Uilleam Blacker, Alexander Etkind, Julie Fedor (red.), Memory and Theory in Eastern Europe, Palgrave Macmillan, New York.

Rossoliński-Liebe Grzegorz, 2014, Stepan Bandera: The Life and Afterlife of a Ukrainian Nationalist, Ibidem-Verlag, Stuttgart.

Rudling Per A., 2011, The OUN, the UPA and the Holocaust: A Study in the Manufacturing of Historical Myths, The Carl Beck Papers in Russian and East European Studies 2107, Center for Russian and East European Studies, Pittsburgh.

Sakowska Magdalena A., 2013, Dziwne przypadki znachora z Polesia. Lokalna legenda, w: Wojciech Lipiński (red.), Dzisiejsze Polesie, DiG, Warszawa.

Skobelewa Oksana, 2013, Dusze zaprzedane diabłu. Miejsca i postacie demoniczne w relacjach mieszkańców Kamianego, w: Wojciech Lipiński (red.), Dzisiejsze Polesie, DiG, Warszawa.

Smyrski Łukasz, Zowczak Magdalena, 2003, (red.), Podole i Wotyń. Szkice etnograficzne, DiG, Warszawa.

Snopek Magdalena, 2013, Przezwiska i przydomki w Sernykach, w: Wojciech Lipiński (red.), Dzisiejsze Polesie, DiG, Warszawa.

Sokołowski Łukasz, 2013, „Łomsk zawsze wierny”. Identyfikacja narodowa Polaków z Tomaszogrodu, w: Wojciech Lipiński (red.), Dzisiejsze Polesie, DiG, Warszawa.

Spittal Stanisław, 1938, Lecznictwo ludowe w Załoźcach i okolicy, „Rocznik Podolski”, t. 1, Tarnopol. Stasiak Barbara, 2009/2010, Świąteczne misterium na Huculszczyźnie, „Kurier Galicyjski”, nr 23-24. Stepaniuk Tomasz, 2013, Poleska cerkiew - miejsce święte, w: Wojciech Lipiński (red.), Dzisiejsze Polesie, DiG, Warszawa. 
Straczuk Justyna, 2006, Cmentarz i stót. Pogranicze prawosławno-katolickie w Polsce i na Biatorusi, Wudawnictwo UWr, Wrocław.

Strojnowski Piotr, 2009, „Drogi ludzi, ludzie drogi. O wędrówkach mieszkańców Bojkowszczyzny przez życie i świat", AIEiAK UW, Lic. 620, Warszawa.

Stryjek Tomasz, 2014, Ukraina przed końcem Historii. Szkice o polityce państw wobec pamięci, ISP PAN-Scholar, Warszawa.

Sulima Tomasz, 2007, „Cztowiek pogranicza”. Próba charakterystyki na przykładach z pogranicza polsko-ukraińskiego, AIEiAK UW, Lic. 557, Warszawa.

Tokarska-Bakir Joanna, 2008, Legendy o krwi. Antropologia przesadu, W.A.B., Warszawa.

Topolski Jerzy (red.), 1981, Świadomość historyczna Polaków. Problemy i metody badawcze, Wydawnictwo Łódzkie, Łódź.

Topolski Jerzy, 1994, Miejsce świadomości historycznej w procesie historycznym, w: Jerzy Topolski (red.), Studia nad świadomością historyczna Polaków, Wydawnictwo Poznańskie, Poznań.

Wąsowska Edyta, 2010, Adaptacja ekonomiczna mieszkańców Stariawy do zmian politycznych zachodzacych na granicy polsko-ukrainskiej od lat 50. XX wieku do czasów wspótczesnych, w: Magdalena Zowczak (red.), Na pograniczu „nowej Europy”. Polsko-ukrainskie sasiedztwo, DiG, Warszawa.

Winter Jay, 2006, Remembering War: The Great War between Memory and History in the $20^{\text {th }}$ Century, Yale University Press, New Haven.

Woźniak Anna, 2007, „Dola czy wybór własny? O staropanieństwie na Bojkowszczyźnie”, AIEiAK UW, Lic. 551, Warszawa.

Woźnica Antoni, 2010, Pamięć mieszkańców nowego pogranicza a tożsamość regionalna, w: Magdalena Zowczak (red.), Na pograniczu „nowej Europy”. Polsko-ukraińskie sąsiedztwo, DiG, Warszawa.

Woźnica Antoni, 2014, „Ukraina w Huculszczyźnie, Huculszczyzna w Ukrainie. Refleksja historyczno-etnograficzna", AIEiAK UW, M. 992, Warszawa.

Zowczak Magdalena, 2010, Antropologia pogranicza. Projekt i realizacja badań, w: Magdalena Zowczak (red.), Na pograniczu „nowej Europy”. Polsko-ukraińskie sasiedztwo, DiG, Warszawa.

Zowczak Magdalena, 2013, Biblia ludowa. Interpretacje wattów biblijnych w kulturze ludowej, Wydawnictwo Naukowe UMK, Toruń.

'THIS UKRAINE, IT'S ALWAYS AT WAR AND AT WAR...': CONCEPTS OF THE PAST IN SOCIAL LIFE IN WESTERN UKRAINE AFTER 1991

\section{Summary}

Research by students of the Institute of Ethnology and Cultural Anthropology of the University of Warsaw, conducted in the years 1992-2010 in various regions of western Ukraine, shows that in rural communities and in areas with low levels of urbanization local ties and knowledge transmitted within the family circle and the neighborhood community play a large role in maintaining identity and a strong group separateness. An important element of local knowledge is imagining about the past. This article describes selected ideas about past and recent history. The author suggests that knowledge about the past is read and interpreted within the framework of a religious worldview, which constitutes the basis of the common cosmology of the communities examined. Hence local narratives about the past have a different nature, and vary both from historiography and from the dominant transmissions in the western Ukrainian national discourse of collective memory. They are actualized in daily life and serve to build adaptive social strategies. 


\section{Key words/słowa kluczowe}

historical consciousness / świadomość historyczna; local narratives about the past / lokalne narracje o przeszłości; ethnographic materials / materiały etnograficzne; folk eschatology / ludowa eschatologia; Ukrainian nationalist discourse / ukraiński dyskurs nacjonalistyczny 